\title{
Relationship between macrocirculation and microcirculation monitored by microdialysis during septic shock
}

\author{
B Meddeb, Z Hajjej, , H Gharsallah, B Trabelsi, I Labbene, M Ferjani \\ From ESICM LIVES 2015 \\ Berlin, Germany. 3-7 October 2015
}

\section{Introduction}

Septic patients need a prompt normalization of macrohemodynamic parameters. Unfortunately, this optimization sometimes does not protect patients from organ failure development. In addition, there are data showing that microcirculatory dysfunction and Cellular metabolic alterations are associated with mortality and can fuel tissue distress leading to organ dysfunction [1].

\section{Objectives}

The aim of our study was to explore the relationships between macrohemodynamic parameters and muscle tissue microdialysis-derived metabolites in critically ill septic patients.

\section{Methods}

Prospective observational study included patients with septic shock admitted to a Tunisian medical -surgical ICU. Each patient was equipped with an arterial and a central venous catheter; patients were also monitored with a pulmonary artery catheter. Treatment for septic shock was standardized according to international recommendations. Microdialysis(MD) catheter was inserted in the femoral quadriceps. Dialysate samples were analyzed for glucose, pyruvate, lactate, and glycerol. The lactate/pyruvate (L/P) ratio was automatically calculated. Sampling was performed at baseline and every $6 \mathrm{~h}$ for 3 days. concomitantly with dialysate sampling, complete hemodynamic measurements were obtained. At the same time blood gases and serum lactate levels were measured. Relation between different parameters were assessed with Spearman's rho test or the Pearson test $\mathrm{p}<0.05$ was considered significant.

\section{Results}

We have included 30 patients with septic shock. A total of 390 measurements were performed. No significant correlation existed between mean arterial pressure (MAP) and tissue metabolites. MD lactate showed a significant, but weak correlation with cardiac index (rho = -0.128, $p=0.007)$. A negative weak correlations were found between systemic oxygen delivery index $\left(\mathrm{DO}_{2} \mathrm{I}\right)$ and tissue lactate $(\mathrm{rho}=-0.234, \mathrm{p}<0.001), \mathrm{L} / \mathrm{P}$ ratio $(\mathrm{rho}=-0.142, \mathrm{p}=0.021)$ and tissue glucose $(\mathrm{rho}=-0.309$, $\mathrm{p}<0.001)$. No significant correlation existed between tissue $\mathrm{L} / \mathrm{P}$ ratio and arterial oxygen partial pressure, mixed-venous oxygen saturation, or Systemic vascular resistance index. A significant positive correlations existed between tissue and blood lactate concentrations (rho $=0.298, \mathrm{P}<0.001)$ and between MD glucose and blood glucose (rho= 0.191, $\mathrm{p}<0.001)$.
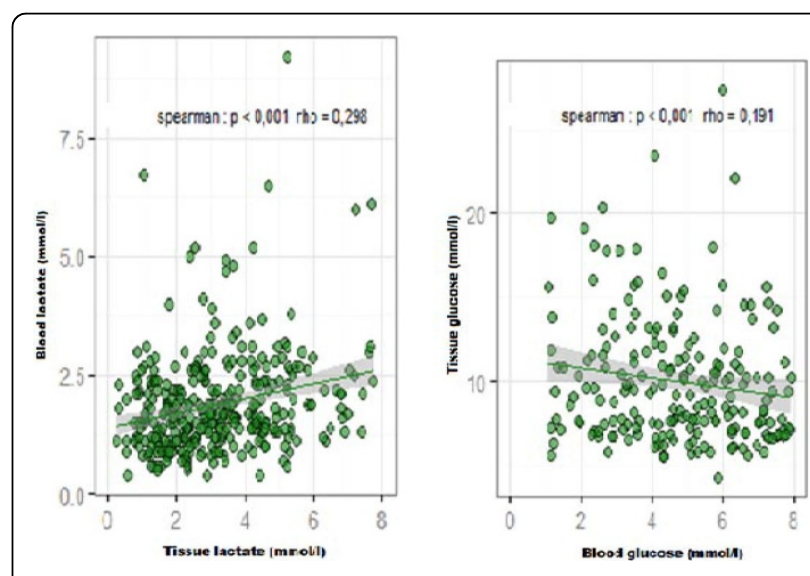

Figure 1 Correlations between tissue and blood lactate. 


\section{Conclusions}

Our results demonstrate a decoupling between macrocirculation and microcirculation. Conventional systemic hemodynamic- and oxygen-derived variables fail to detect such microcirculatory dysfunction and its response to the therapy in sepsis. Therefore, rather than limiting therapy to macrocirculatory targets alone, microcirculatory targets could be incorporated to potentially reduce mortality rates in these critically ill patients.

Published: 1 October 2015

\section{Reference}

1. Levy B, Perez P, Gibot S, Gerard A: Increased muscle-to-serum lactate gradient predicts progression towards septic shock in septic patients. Intensive Care Med 2010, 36(10):1703-1709.

doi:10.1186/2197-425X-3-S1-A522

Cite this article as: Meddeb et al:: Relationship between

macrocirculation and microcirculation monitored by microdialysis

during septic shock. Intensive Care Medicine Experimental 2015

3(Suppl 1):A522.

\section{Submit your manuscript to a SpringerOpen ${ }^{\mathcal{O}}$ journal and benefit from:}

- Convenient online submission

- Rigorous peer review

- Immediate publication on acceptance

- Open access: articles freely available online

- High visibility within the field

- Retaining the copyright to your article 